\title{
Pengaruh Pendidikan, Pendapatan dan Konsumsi Terhadap Kemiskinan Masyarakat Migran Di Kota Makassar Jurnal Ecces
}

\author{
Abdul Rahman ${ }^{1}$ \\ Muh. Fiqram Alamsyah ${ }^{2}$ \\ Program Studi Ilmu Ekonomi \\ Fakultas Ekonomi dan Bisnis Islam Universitas Islam Negeri Alauddin Makassar \\ Jl. Yasin Limpo, No. 36 Samata, Gowa Sulawesi Selatan \\ E-mail: abdulrahman1582@gmail.com falamsyach@gmail.com
}

\section{Abstrak: Pengaruh Pendidikan, Pendapatan Dan Konsumsi Terhadap Kemiskinan Masyarakat Migran Di Kota Makassar}

Penelitian ini dilakukan untuk mengukur pengaruh dari tingkat pendidikan, pendapatan, terhadap konsumsi dan kemiskinan yang dilihat dari nilai kepemilikan aset di kota Makassar, dan masyarakat migran sebagai obyek penelitiannya dengan menggunakan model analisis regresi linear berganda dan analisis jalur (path). Jenis penelitian yang dilakukan dalam penelitian ini yaitu jenis penelitian kuantitatif dengan menggunakan data primer. Data primer ini diperoleh dari kuesioner yang dibagikan kepada responden yaitu masyarakat migran yang berada di Kota Makassar. Data tersebut kemudian diolah di program excel dan di analisis menggunakan program SPSS versi 21 dengan metode analisis regresi linear berganda dan analisis jalur (path). Hasil penelitian menunjukkan bahwa: 1) Pendidikan tidak berpengaruh signifikan dan berpengaruh negatif terhadap konsumsi masyarakat migran di Kota Makassar, 2) Pendapatan berpengaruh signifikan dan berpengaruh positif terhadap tingkat konsumsi masyarakat migran di Kota Makassar, 3) Pendidikan tidak berpengaruh signifikan dan berpengaruh negatif terhadap tingkat kemiskinan masyarakat migran di Kota Makassar, 4) Pendapatan berpengaruh signifikan dan berpengaruh negatif terhadap tingkat kemiskinan masyarakat migran di Kota Makassar, 5) Konsumsi tidak berpengaruh signifikan dan berpengaruh negatif terhadap tingkat kemiskinan masyarakat migran di Kota Makassar, 6) Pendidikan berpengaruh terhadap tingkat kemiskinan melalui konsumsi masyarakat migran di Kota Makassar, 7) Pendapatan berpengaruh terhadap tingkat kemiskinan melalui konsumsi masyarakat migran di Kota Makassar

Kata kunci: Pendapatan, Konsumsi, Kemiskinan, Masyarakat Migran. 


\section{Abstrct: Effect of Education, Income and Consumption on Poverty of Migrant Communities in Makassar City.}

Effects of Education, Revenue, on Consumption and Poverty. This research was conducted to measure the influence of education, income, consumption and poverty as seen from the value of asset ownership in the city of Makassar, and the migrant community as the object of research using a multiple linear regression analysis and path analysis. The type of research conducted in this study is a type of quantitative research using primary data. Primary data obtained from questionnaires distributed to respondents namely migrant communities in the city of Makassar. The data is then processed in an excel program and analyzed using the SPSS version 21 program with a linear multiple regression analysis method and path (path) analysis. The results showed that: 1) Education was not significant and had a negative effect on public consumption in Makassar City, 2) Significant income and a positive effect on public consumption in Makassar City, 3) Education was not significant and negatively affected the level of migrants in the poor city of Makassar , 4) Significant income and a negative effect on migrant poor people in Makassar City, 5) Consumption is not significant and negatively affects the level of poverty of migrant communities in Makassar City, 6) Consumption of migrant communities in Makassar City, 7) Income earned from consumption levels migrant community in Makassar City.

Keywords: Income, Consumption, Poverty, Migrant Society. 


\section{PENDAHULUAN / INTRODUCTION}

Kemiskinan bukanlah tragedi kemanusiaan akibat kejahatan alam (Yustika, 2009). Kemiskinan bukanlah entitas tunggal yang muncul dengan sendirinya. Kemiskinan didasari oleh berbagai faktor yang saling berkaitan satu sama lain sehingga menimbulkan konflik sosial-ekonomi yang berkelanjutan. Badan Pusat Statistik (BPS) menjelaskan bahwa kemiskinan adalah ketidakmampuan memenuhi standar minimum kebutuhan, baik kebutuhan makanan maupun non-makanan. Menurut BPS pula bahwa kemiskinan adalah kondisi seseorang yang hanya mampu memenuhi kebutuhan makannya kurang dari 2100 kalori perkapita perhari (Maulidah, 2015).

Di era kekinian, masalah kemiskinan menjadi lebih kompleks dengan akar permasalahannya menyentuh dimensi ekonomi maupun non-ekonomi. Berbagai aspek yang saling berkaitan satu sama lain menyebabkan adanya hubungan kausalitas dari kedua dimensi tersebut sehingga berkontribusi dalam menimbulkan kemiskinan secara individu maupun massal. Hal ini sejalan dengan teori "lingkaran setan kemiskinan" dari Nurkse yang mengatakan adanya keterkaitan antara faktor satu dengan lainnya sehingga membentuk sebuah siklus kausalitas satu sama lain.

Nurkse menjelaskan: "Lingkaran setan mengandung arti deretan melingkar kekuatankekuatan yang satu sama lain beraksi dan bereaksi sedemikian rupa sehingga menempatkan suatu negara miskin tetap berada dalam keadaan melarat. Si miskin, misalnya, selalu kurang makan; karena kurang makan, kesehatannya menjadi buruk; karena fisiknya lemah kapasitas kerjanya rendah; karena kapasitas kerjanya rendah penghasilannya pun rendah, dan itu berarti ia miskin, akhirnya ia tidak akan mempunyai cukup makan; dan seterusnya. Bila keadaan seperti ini dikaitkan dengan negara secara keseluruhan dapat dikemas ke dalam dalil kuno: 'Suatu negara miskin karena ia miskin" (Jhinggan, 2014).

Jika dikaji lebih dalam lagi, masyarakat migran merupakan salah satu bagian dari penyumbang terbesar angka kemiskinan di daerah perkotaan. Kemiskinan yang tinggi di tingkat pedesaan mendorong masyarakat daerah setempat berlomba-lomba untuk mencari kehidupan yang lebih layak. Salah satu cara yang paling sering dilakukan dengan cara Urbanisasi.

Stigma daerah perkotaan yang menjanjikan kesejahteraan di benak masyarakat pedesaan, kemudian menjadi alasan mengapa perpindahan penduduk dari desa ke kota (urbanisasi) menjadi rutinitas tahunan, bulanan, bahkan harian di daerah perkotaan. Banyaknya masyarakat desa yang "mengadu nasib" di daerah perkotaan dengan motivasi 
yang berbeda-beda, mulai dari motivasi ekonomi, sosial, adat, hingga politik menjadikan daerah perkotaan cenderung lebih padat.

Pada dasarnya urbanisasi merupakan konsekuensi logis dari pembangunan daerah perkotaan itu sendiri. Terpusatnya kegiatan ekonomi di daerah perkotaan menyebabkan masyarakat desa berlomba-lomba mencari pekerjaan yang lebih menjanjikan dibandingkan menjadi petani (di lahan orang lain). Hal ini tentu saja tidak salah. Yang menjadi masalah kemudian, ketika motivasi ekonomi tersebut tidak disertai modal yang cukup untuk bersaing di dunia kerja profesional.

Meskipun tidak semua, namun kebanyakan masyarakat migran melakukan urbanisasi dengan "modal nekat" saja. Hal ini tentu saja menyebabkan permasalahan lain yang lebih besar, di samping kepadatan penduduk. Minimnya kompetensi atau tingkat pendidikan menyebabkan peluang untuk mendapatkan pekerjaan yang lebih layak juga semakin kecil. Akibatnya pendapatan masyarakat tersebut juga tidak meningkat, bahkan tidak jarang hanya menjadi beban pembangunan di tengah getirnya kehidupan perkotaan. Kondisi ini akan mempengaruhi tingkat konsumsi masyarakat tersebut, dan pada akhirnya menghasilkan penduduk miskin yang baru. Hal ini mengindikasikan bahwa ada hubungan sebab-akibat (kausalitas) dari tingkat pendidikan, pendapatan, juga konsumsi terhadap meningkatnya kemiskinan di tengah masyarakat.

Salah satu kasus yang berkaitan dengan permasalahan diatas yaitu yang terjadi pada masyarakat migran di kota Makassar. Pertumbuhan penduduk yang kian hari kian meningkat menjadi permasalahan tersendiri bagi pemerintah kota setempat. Sebagian dari jumlah kemiskinan kota merupakan produk dari urbanisasi. Data dari Dinas Kependudukan Kota Makassar memperlihatkan bahwa dalam kurun waktu 7 tahun terakhir tingkat migrasi masuk di Kota Makassar mengalami fluktuasi namun cenderung meningkat. Dari kurun waktu tahun 2011 hingga 2017, hanya pada tahun 2012 dan 2016 migrasi masuk dapat diminimalisir, dan yang paling tinggi terjadi pada tahun 2017 yaitu sebesar 111.417. Hal ini tentu saja mengejutkan setelah setahun sebelumnya berhasil diminimalisir, namun kembali meningkat cukup pesat di tahun berikutnya.

Adanya masyarakat migran yang melakukan urbanisasi tanpa modal yang cukup, dalam hal ini pendidikan, menyebabkan mereka kesulitan mendapatkan pekerjaan yang layak di daerah perkotaan. Motivasi ekonomi yang lebih mengarah pada keinginan untuk meningkatkan pendapatan, "telah mendorong arus migrasi ke kota untuk memperoleh lapangan pekerjaan yang walaupun sempit tetapi upahnya tinggi, Namun yang terjadi malah sebaliknya. Pendidikan yang minim menjadikan mereka hanya sebagai pelengkap dari tingkat kemiskinan kota. "Kecenderungan untuk memberi kesempatan kerja dengan upah yang tinggi kepada mereka yang berpendidikan tinggi" (Todaro, 2000), menyebabkan 
mereka yang berpendidikan rendah menjadi minim kesempatan untuk memenuhi kebutuhan pasar pekerja. Hal ini banyak terjadi pada masyarakat migran di Kota Makassar. Seringkali kita temui pekerja pada sektor-sektor informal (tukang becak, pemulung, supir angkutan umum, dan lain-lain) di kota Makassar berasal dari masyarakat migran dari berbagai daerah.

Berdasarkan latar belakang di atas maka penulis tertarik untuk membahas mengenai jumlah penduduk miskin di kota Makassar, khususnya bagi masyarakat migran yang menetap di Kota Makassar. Selain itu di dalam penelitian ini juga akan dilihat bagaimana pengaruh langsung dan tidak langsung variabel tingkat pendidikan, jumlah pendapatan, dan konsumsi terhadap jumlah penduduk miskin masyarakat migran di kota Makassar.

\section{TINJAUAN TEORITIK / LITERATURE REVIEW}

\section{Teori Kemiskinan}

Badan Pusat Statistik (BPS) menjelaskan bahwa kemiskinan adalah ketidakmampuan memenuhi standar minimum kebutuhan, baik kebutuhan makanan maupun non makanan. Menurut BPS pula bahwa kemiskinan adalah kondisi seseorang yang hanya mampu memenuhi kebutuhan makannya kurang dari 2100 kalori perkapita per hari (BPS, 2018). Dalam arti proper kemiskinan dipahami sebagai keadaan kekurangan uang dan barang untuk menjamin kelangsungan hidup. Dalam arti luas, kemiskinan merupakan suatu fenomena multiface atau multidimensional (Suryawati, 2005). Hidup dalam kemiskinan bukan hanya hidup dalam kekurangan uang dan tingkat pendapatan rendah, tetapi juga banyak hal lain, seperti: tingkat kesehatan, pendidikan rendah, perlakuan tidak adil dalam hukum, kerentanan terhadap ancaman tindak kriminal, ketidakberdayaan menghadapi kekuasaan, dan ketidakberdayaan dalam menentukan jalan hidupnya sendiri. ${ }^{3}$ Kemiskinan dapat dibagi dalam empat bentuk, yaitu:

1) Kemiskinan absolut: bila pendapatannya di bawah garis kemiskinan atau tidak cukup untuk memenuhi pangan, sandang, kesehatan, perumahan, dan pendidikan yang diperlukan untuk bisa hidup dan bekerja.

2) Kemiskinan relatif: kondisi miskin karena pengaruh kebijakan pembangunan yang belum menjangkau seluruh masyarakat, sehingga menyebabkan ketimpangan pada pendapatan.

3) Kemiskinan kultural: mengacu pada persoalan sikap seseorang atau masyarakat yang disebabkan oleh faktor budaya, seperti tidak mau berusaha memperbaiki 
tingkat kehidupan, malas, pemboros, tidak kreatif meskipun ada bantuan dari pihak luar.

4) Kemiskinan struktural: situasi miskin yang disebabkan karena rendahnya akses terhadap sumber daya yang terjadi dalam suatu sistem sosial budaya dan sosial politik yang tidak mendukung pembebasan kemiskinan, tetapi seringkali menyebabkan suburnya kemiskinan (Suryawati, 2005).

Lebih Lanjut Suryawati (2005), menjelaskan Kemiskinan juga dapat dibedakan menjadi dua jenis yaitu kemiskinan alamiah dan kemiskinan buatan (artificial).

1) Kemiskinan alamiah berkaitan dengan kelangkaan sumber daya alam dan prasarana umum, serta keadaan tanah yang tandus.

2) Kemiskinan buatan lebih banyak diakibatkan oleh sistem modernisasi atau pembangunan yang membuat masyarakat tidak dapat menguasai sumber daya, sarana, dan fasilitas ekonomi yang ada secara merata.

Negara terbelakang umumnya akan terjerat dalam kondisi dimana sulitnya melakukan pembangunan dikarenakan adanya suatu rangkaian yang saling mempengaruhi sehingga membuat negara tersebut akan tetap miskin. Kondisi ini biasa disebut "lingkaran setan kemiskinan" oleh Nurkse. Lebih lanjut Nurkse menjelaskan: "Lingkaran setan mengandung arti deretan melingkar kekuatan-kekuatan yang satu sama lain beraksi dan bereaksi sedemikian rupa sehingga menempatkan suatu negara miskin tetap berada dalam keadaan melarat. Si miskin, misalnya, selalu kurang makan; karena kurang makan, kesehatannya menjadi buruk; karena fisiknya lemah kapasitas kerjanya rendah; karena kapasitas kerjanya rendah penghasilannya pun rendah, dan itu berarti ia miskin, akhirnya ia tidak akan mempunyai cukup makan; dan seterusnya. Bila keadaan seperti ini dikaitkan dengan negara secara keseluruhan dapat dikemas ke dalam dalil kuno: 'Suatu negara miskin karena ia miskin" (Jhinggan, 2014).

Menurut Nurkse ada 2 perangkap lingkaran kemiskinan, yaitu dari segi permintaan (demand) dan penawaran (supply).

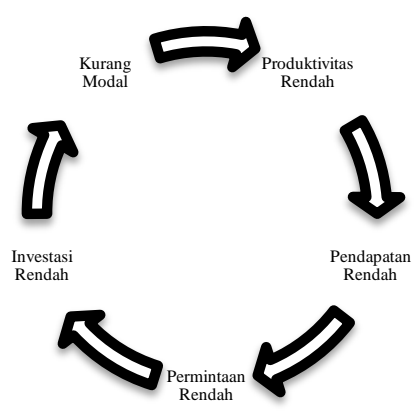

Gambar 1

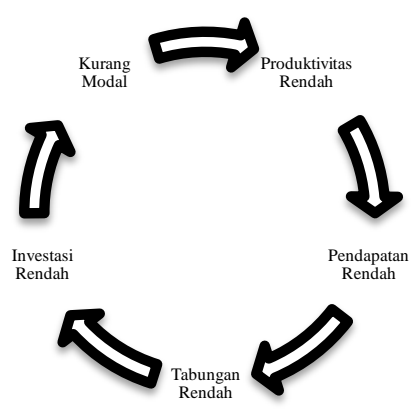

Gambar 2 


\section{Sumber: Jhinghan, 2014 (Dimodifikasi Penulis)}

Dari segi permintaan (demand), di negara-negara yang miskin perangsang untuk menanamkan modal adalah sangat rendah, karena luas pasar untuk berbagai jenis barang adanya terbatas, hal ini disebabkan oleh karena pendapatan masyarakat sangat rendah. Pendapatan masyarakat sangat rendah karena tingkat produktivitas yang rendah, sebagai wujud dari tingkatan pembentukan modal yang terbatas di masa lalu. Pembentukan modal yang terbatas disebabkan kekurangan perangsang untuk menanamkan modal dan seterusnya. Sebagaimana yang digambarkan pada gambar 1 (Anggraini, 2012). Sedangkan dari segi penawaran (supply) tingkat pendapatan masyarakat yang rendah yang diakibatkan oleh tingkat produktivitas yang rendah menyebabkan kemampuan masyarakat untuk menabung rendah. Kemampuan untuk menabung rendah, menyebabkan tingkat pembentukan modal yang rendah, tingkat pembentukan modal (investasi) yang rendah menyebabkan kekurangan modal, dan dengan demikian tingkat produktivitasnya juga rendah dan seterusnya 1 (Anggraini, 2012). Hal tersebut dapat dilihat pada gambar 2.

Menurut Ustama (2009), kemiskinan tidak lagi dipahami hanya sebatas ketidakmampuan ekonomi, tetapi juga kegagalan memenuhi hak-hak dasar dan perbedaan perlakuan bagi seseorag atau kelompok orang dalam menjalani kehidupan secara bermartabat. Sedangkan hak-hak dasar yang diakui secara umum adalah terpenuhinya kebutuhan pangan, kesehatan, pendidikan, pekerjaan, perumahan, air bersih, pertanahan dan lingkungan hidup, rasa aman dari perlakuan atau ancaman tindak kekerasan dan hal-hal untuk berpartisipasi dalam keidupan sosial politik baik perempuan maupun laki-laki. Membahas peranan pendidikan dalam pengentasan kemiskinan harus diarahkan human capability (Sen, 2000). Dengan pendidikan yang baik, setiap orang memiliki bekal pengetahuan dan keterampilan, mempunyai pilihan untuk mendapat pekerjaan, dari menjadi lebih produktif sehingga dapat meningkatkan pendapatan. Dengan demikian pendidikan dapat memutus mata rantai kemiskinan dan menghilangkan eksklusi sosial, untuk kemudian meningkatkan kualitas hidup dan mewujudkan kesejahteraan masyarakat.

Filosofis Amartya Sen, paham libertarianisme Nosick dan Jeffrey Sachs mengemukakan enam paket penuntasan kemiskinan, yaitu: 1) Kapital manusia (human capital) terutama dalam kesehatan, gizi, dan ketrampilan yang diperoleh melalui pendidikan dan pelatihan; 2) Kapital bisnis (business capital), sarana-sarana yang diperlukan di dalam transportasi untuk pertanian, industri dan servis; 3) Infrastruktur: jalan, tenaga listrik, air 
minum. Sanitasi, dan sebagainya; 4) Kapital alamiah (natural capital) berupa tanah pertanian, biodipersitas; 5) Kapital lembaga-lembaga publik seperti hukum dagang, hukum peradilan, pelayanan pemerintah; 6) Kapital ilmu pengetahuan (knowledge capital) berupa know how ilmu dan teknologi yang meningkatkan produktivitas yang dapat meningkatkan natural capital.

Pengaruh Antar Variabel

1. Pengaruh Tingkat Pendidikan Terhadap Konsumsi

Rahardja dkk dalam Karmini (2012) mengemukakan bahwa semakin tinggi pendidikan seseorang pengeluaran konsumsinya juga akan semakin tinggi, sehingga mempengaruhi pola konsumsi dan hubungannya positif. Pada saat seseorang atau keluarga memiliki pendidikan yang tinggi, kebutuhan hidupnya semakin banyak. Kondisi ini disebabkan karena yang harus mereka penuhi bukan hanya sekedar kebutuhan untuk makan dan minum, tetapi juga kebutuhan informasi, pergaulan di masyarakat baik, dan kebutuhan akan pengakuan orang lain terhadap keberadaannya (Karmini, 2012).

\section{Pengaruh Tingkat Pendidikan Terhadap Kemiskinan}

Tingkat kemiskinan juga dapat disebabkan oleh rendahnya pertumbuhan ekonomi dan jumlah penduduk yang sangat besar, serta tingkat pendidikan masyarakat. Pendidikan adalah pionir dalam pembangunan masa depan suatu bangsa, karena pendidikan yang berkualitas dapat menentukan kualitas dari pembangunan. Melalui pendidikan, maka generasi manusia yang berkualitas dapat terlahir dan juga dengan lahirnya manusia yang berkualitas maka dapat menghasilkan pembangunan yang berkualitas dan maksimal. Oleh karena itu setiap manusia haruslah selalu memperbaiki kualitas dirinya melalui pendidikan yang dilakukan dengan professional agar tujuan untuk pembangunan yang berkualitas akan tercapai dan berhasil dengan baik (Amalia, 2017).

\section{Pengaruh Tingkat Pendapatan Terhadap Konsumsi}

Tingkat konsumsi memberikan gambaran tingkat kemakmuran seseorang atau suatu masyarakat. Semakin tinggi tingkat konsumsi,semakin sejahtera seseorang. Sebaliknya semakin rendah tingkat konsumsi, berarti semakin miskin. Untuk dapat mengkonsumsi seseorang harus mempunyai pendapatan. Apabila pendapatan meningkat, seseorangdapat mengkonsumsi barang dalam jumlah yang lebih banyak, namun tidak semuapendapatan digunakan untuk konsumsi,akan tetapi bagi seseorang yang memiliki kelebihan pendapatan setelah konsumsi akan digunakan untuk menabung (Mahyu, 2013).

\section{Pengaruh Tingkat Pendapatan Terhadap Kemiskinan}


Pendapatan merupakan salah satu indikator dari kemiskinan. Rendahnya tingkat pendapatan yang diperoleh masyarakat akan menyebabkan tidak terpenuhinya kebutuhan hidupnya, sehingga dapat dikatakan seseorang dengan pendapatan yang rendah disebut masyarakat miskin. Sehingga dapat diyakini bahwa terdapat pengaruh langsung antara pendapatan dengan kemiskinan.

\section{Pengaruh Tingkat Konsumsi Terhadap Kemiskinan}

Sebagaimana diketahui bahwa untuk menyebut seseorang itu miskin, digunakan garis kemiskinan sebagai indikatornya yang biasa diukur berdasarkan jumlah konsumsi kalori. Dengan demikian, seharusnya diantara faktor konsumsi total dengan tingkat kemiskinan ada faktor antaranya yakni konsumsi kalori. Akan tetapi konsumsi kalori tidak dimasukkan, sehingga dianggap konsumsi total memiliki pengaruh langsung terhadap tingkat kemiskinan, tanpa ada faktor perantaranya (Anggraini, 2012).

\section{METODE PENELITIAN / METHODS}

Penelitian yang digunakan penulis merupakan jenis penelitian deskriptif kuantitatif dengan memaparkan fenomena yang ada di tengah masyarakat serta menggunakan angkaangka untuk menjabarkan karakteristik permasalahan dan hasil penelitian yang akan dipaparkan. Data yang digunakan dalam penelitian ini menggunakan metode sebagai berikut: 1) Library Research (Penelitian Kepustakaan); 2) Yaitu penelitian yang dilakukan dengan studi kepustakaan dari berbagai literatur untuk memperoleh informasi atau peralatan dasar yang berkaitan dengan penelitian. Seperti, majalah-majalah, buletin-buletin, jurnal-jurnal, serta bahan bacaan lainnya yang ada kaitannya dengan masalah yang diteliti khususnya masalah-masalah yang berkaitan dengan penelitian ini; 3) Observasi, Yaitu penelitian yang langsung dilakukan di tempat terkait yang menyediakan data dan informasi yang berkaitan dengan penelitian ini; 4) Kuesioner, Yaitu teknik yang menggunakan pertanyaan maupun pernyataan tertulis yang dibagikan kepada setiap responden untuk mendapatkan informasi dari reponden berdasarkan data-data yang dibutuhkan.

Populasi yang diambil yaitu jumlah masyarakat yang ada di Kota Makassar berdasarkan data yang diperoleh dari Badan Pusat Statistik Kota Makassar yaitu jumlah migrasi masuk sebesar 111.417 jiwa.

Penelitian ini menggunakan pengambilan metode random, dimana pengambilan random adalah bahwa semua populasi memiliki kesempatan yang sama untuk diambil 
sebagai sampel, yang kemudian dijadikan sebagai responden dalam penelitian ini. Dan untuk menentukan sampel pada penelitian ini yang populasinya berjumlah 111.417 jiwa di Kota Makassar dapat dihitung menggunakan rumus Slovin sehingga diperoleh hasil 99,91 dan dibulatkan menjadi 100 reponden.

\section{Metode Analisis Data}

Metode analisis yang digunakan dalam penulisan ini adalah metode analisis path atau analisis jalur. Metode ini untuk memperlihatkan pengaruh langsung antara variabel bebas dan variabel tidak bebas. Berdasarkan model konseptual pada gambar kerangka pikir, maka dapat dibentuk persamaan fungsional dalam model reduced form sebagai berikut:

$Y_{1}=f\left(X_{1}, X_{2}\right)$

$Y_{2}=f\left(X_{1}, X_{2}, Y_{1}\right)$

Dimana:

$\mathrm{X}_{1} \quad=$ Tingkat Pendidikan

$\mathrm{X}_{2} \quad=$ Pendapatan

$\mathrm{Y}_{1} \quad=$ Konsumsi

$\mathrm{Y}_{2} \quad=$ Kemiskinan

Persamaan di atas dapat di tulis kembali menjadi:

$Y_{1}=a_{0}+a_{1} X_{1}+a_{2} X_{2}+\mu_{1}$

$Y_{2}=\beta_{0}+\beta_{1} X_{1}+\beta_{2} X_{2}+\beta_{3} Y_{1}+\mu_{2}$

Untuk mengistemasi persamaan di atas, tidak dapat dilakukan dengan OLS (Ordinary Least Square) sebelum dilakukan indetifikasi koefisien dengan memindahkan semua variabel endogen kesebelah kiri dan variabel eksogen ke sebelah kanan, sebagai berikut:

$\mathrm{Y}_{1}=\mathrm{a}_{0}+\mathrm{a}_{1} \mathrm{X}_{1}+\mathrm{a}_{2} \mathrm{X}_{2}+\mu_{1}$

$Y_{2}=\beta_{0}+\beta_{1} X_{1}+\beta_{2} X_{2}+\beta_{3} Y_{1}+\mu_{2}$

Sehingga diperoleh reduced form sebagai berikut:

$\mathrm{Y}_{1}=\mathrm{a}_{0}+\mathrm{a}_{1} \mathrm{X}_{1}+\mathrm{a}_{2} \mathrm{X}_{2}+\mu_{1}$

$Y_{2}=\beta_{0}+\beta_{1} X_{1}+\beta_{2} X_{2}+\beta_{3} Y_{1}+\beta_{4}\left(a_{0}+a_{1} X_{1}+a_{2} X_{2}+\mu_{1}\right)+\mu_{2}$

$Y_{1}-Y_{2}=\beta_{0}+\left(\beta_{1}+\beta_{3} a_{1}\right) X_{1}+\left(\beta_{2}+\beta_{3} a_{2}\right) X_{2}+\left(\beta_{3}+\beta_{3} a_{3}\right) Y_{1}+\beta_{3} a_{0}+\beta_{3} a_{1}+\mu_{2}$

Dimana :

Konstanta

$\mathrm{a}_{0} \quad=$ Konstanta untuk $\mathrm{Y}_{1}$

$\beta_{0} \quad=$ Konstanta untuk $Y_{2}$

Pengaruh Lansung (Direct effect)

$\mathrm{a}_{1} \quad=$ Pengaruh langsung Tingkat Pendidikan $\left(\mathrm{X}_{1}\right)$ terhadap Konsumsi $\left(\mathrm{Y}_{1}\right)$

$\mathrm{a}_{2} \quad=$ Pengaruh langsung Pendapatan $\left(\mathrm{X}_{2}\right)$ terhadap Konsumsi $\left(\mathrm{Y}_{1}\right)$

$\beta_{1} \quad=$ Pengaruh langsung Pendidikan $\left(X_{1}\right)$ terhadap Kemiskinan $\left(Y_{2}\right)$ 
$\beta_{2} \quad=$ Pengaruh langsung Pendapatan $\left(\mathrm{X}_{2}\right)$ terhadap Kemiskinan $\left(\mathrm{Y}_{2}\right)$

$\beta_{3} \quad=$ Pengaruh langsung Konsumsi $\left(Y_{1}\right)$ terhadap Kemiskinan $\left(Y_{2}\right)$

Pengaruh Tidak Langsung (Indirect effect)

$\beta_{3} a_{1}=$ Pengaruh tidak langsung Pendidikan $\left(X_{1}\right)$ terhadap Kemiskinan $\left(Y_{2}\right)$ melalui Konsumsi $\left(\mathrm{Y}_{1}\right)$

$\beta_{3} a_{2}=$ Pengaruh tidak langsung Pendapatan $\left(X_{2}\right)$ terhadap Kemiskinan $\left(Y_{2}\right)$ melalui Konsumsi $\left(\mathrm{Y}_{1}\right)$

Total pengaruh ( Total effect)

$\left(\beta_{1}+\beta_{3} a_{1}\right)=$ Total pengaruh Pendidikan $\left(X_{1}\right)$ terhadap Kemiskinan $\left(Y_{2}\right)$

$\left(\beta_{2}+\beta_{3} a_{2}\right)=$ Total pengaruh Pendapatan $\left(X_{2}\right)$ terhadap Kemiskinan $\left(Y_{2}\right)$

1. Error Term

$\mu_{1} \quad=$ Error Term $\mathrm{Y}_{1}$

$\mu_{2} \quad=$ Error Term $\mathrm{Y}_{2}$

\section{HASIL DAN PEMBAHASAN / DISCUSSION}

Berdasarkan model analisis regresi maka diperoleh hubungan antara setiap variabel. Adapun pengaruh masing-masing variabel bebas terhadap variabel terikat dalam sebuah model regresi dapat dilihat dari nilai-nilai koefisien dan tingkat signifikansi masing-masing pada sebuah analisis sebagai berikut:

Model 1: $Y_{1}=a_{0}+a_{1} X_{1}+a_{2} X_{2}+\mu_{1}$ Model 1: $Y_{1}=3,180-0,140 X_{1}+0,759 X_{2}+0,433$

Hasil dari persamaan regresi di atas dapat di interpretasikan sebagai berikut:

1. Nilai koefesien $a_{0}$ sebesar 3,180. Jika variabel tingkat pendidikan (X1) dan pendapatan (X2) tidak mengalami perubahan atau konstan, maka akan terjadi peningkatan konsumsi (Y1) sebesar 3,180.

2. Nilai koefesien $a_{1}$ sebesar -0,140. Hal ini menunjukkan bahwa jika terjadi peningkatan tingkat pendidikan (X1) maka akan menurunkan tingkat konsumsi (Y1) sebesar 0,140.

3. Nilai koefesien $a_{2}$ sebesar 0,759 . Hal ini menunjukkan bahwa jika terjadi peningkatan tingkat pendapatan (X2) maka akan meningkatkan tingkat konsumsi (Y1) sebesar 0,759.

Model 2: $Y_{2}=\beta_{0}+\beta_{1} X_{1}+\beta_{1} X_{2}+\beta_{3} Y_{1}+\mu_{2}$ Model 2: $Y_{2}=-9,840-0,433 X 1-1,617 X 2-0,618 Y 1+1,521$ 
Hasil dari persamaan regresi di atas dapat di interpretasikan sebagai berikut:

1. Nilai koefesien $\beta 0$ sebesar -9,840. Jika variabel tingkat pendidikan (X1), pendapatan (X2), dan konsumsi (Y1) tidak mengalami perubahan atau konstan, maka akan terjadi penurunan kemiskinan (Y2) sebesar 9,840.

2. Nilai koefisien $\beta 1$ sebesar -0,433. Hal ini menunjukkan bahwa jika terjadi peningkatan tingkat pendidikan (X1) maka akan menurunkan tingkat kemiskinan (Y2) sebesar 0,433 dengan asumsi bahwa variabel tingkat pendapatan (X2) dan konsumsi (Y1) dianggap konstan.

3. Nilai koefisien $\beta 2$ sebesar -1,617. Hal ini menunjukkan bahwa jika terjadi peningkatan pendapatan (X2) maka akan menurunkan kemiskinan (Y2) sebesar 1,617 dengan asumsi bahwa variabel tingkat pendidikan (X1) dan konsumsi (Y1) dianggap konstan.

4. Nilai koefisien $\beta 3$ sebesar -0,168. Hal ini menunjukkan bahwa jika terjadi peningkatan konsumsi (Y1) maka akan menurunkan kemiskinan (Y2) sebesar 0,168 dengan asumsi bahwa variabel tingkat pendidikan (X1) dan pendapatan (X2) dianggap konstan.

Tabel 1, merupakan distribusi nilai pengaruh langsung, tidak langsung, dan pengaruh total antar variabel. Jalur langsung merupakan pengaruh langsung dari suatu variabel bebas ke variabel terikat, sedangkan jalur tidak langsung merupakan pengaruh yang melalui suatu variabel antara atau variabel intervening.

Tabel 1

Pengaruh Pendidikan, Pendapatan, dan Konsumsi Terhadap Kemiskinan

\begin{tabular}{ccccc}
\hline $\begin{array}{c}\text { Pengaruh antar } \\
\text { variable }\end{array}$ & $\begin{array}{c}\text { Pengaruh } \\
\text { Langsung }\end{array}$ & $\begin{array}{c}\text { Tingkat } \\
\text { Signifikansi }\end{array}$ & $\begin{array}{c}\text { Pengaruh Tidak } \\
\text { Langsung Melalui }\end{array}$ & Total Pengaruh \\
\hline $\mathrm{X} 1 \rightarrow \mathrm{Y} 1$ & $-0,140$ & 0,383 & - & $-0,140$ \\
\hline $\mathrm{X} 2 \rightarrow \mathrm{Y} 1$ & 0,759 & $0,000^{*}$ & - & 0,759 \\
\hline $\mathrm{X} 1 \rightarrow \mathrm{Y} 2$ & $-0,433$ & 0,444 & 0,023 & $-0,410$ \\
\hline $\mathrm{X} 2 \rightarrow \mathrm{Y} 2$ & $-1,617$ & $0,000 *$ & $-0,127$ & $-1,744$ \\
\hline $\mathrm{Y} 1 \rightarrow \mathrm{Y} 2$ & $-0,168$ & 0,638 & - & $-0,168$ \\
\hline
\end{tabular}

Sumber: Olahan data primer tahun 2019

Ket.: * adalah data signifikan $(<0,05)$

\section{Uji Hipotesis}

\section{Model 1 (Y1)}

\section{a. Uji simultan (uji F)}

Uji F merupakan uji secara simultan untuk mengetahui apakah variabel tingkat pendidikan dan pendapatan secara simultan mempunyai pengaruh yang signifikan terhadap konsumsi. Dari hasil analisis dapat dilihat pada tabel 2 berikut: 
Tabel 2

Hasil Uji Simultan (uji F)

\begin{tabular}{llrrrrr}
\hline \multicolumn{7}{c}{ ANOVA $^{\mathbf{a}}$} \\
\hline Model & Sum of Squares & Df & $\begin{array}{c}\text { Mean } \\
\text { Square }\end{array}$ & $\mathrm{F}$ & Sig. \\
\hline \multirow{3}{*}{1} & Regression & 32,405 & 2 & 16,202 & 86,097 &, $000^{\mathrm{b}}$ \\
\cline { 2 - 7 } & Residual & 18,254 & 97 &, 188 & \\
\cline { 2 - 7 } & Total & 50,659 & 99 & & & \\
\hline
\end{tabular}

a. Dependent Variable: Konsumsi

b. Predictors: (Constant), Pendapatan, Pendidikan

Dari hasil regresi yang ditunjukkan pada tabel 2. Pengaruh variabel tingkat pendidikan (X) dan pendapatan (X2) terhadap konsumsi (Y1) maka diperoleh tingkat signifikansi $0,000<0,05$. Hal ini dapat menunjukkan bahwa kedua variabel tersebut, yakni pendidikan $(X)$ dan pendapatan (Y1) secara simultan berpengaruh signifikan terhadap variabel konsumsi.

b. Uji Parsial (Uji t)

Tabel 3

Hasil Uji Parsial (uji t)

Coefficients $^{\mathrm{a}}$

\begin{tabular}{|c|c|c|c|c|c|c|}
\hline$\overline{\text { Mode }}$ & & \multicolumn{2}{|c|}{ Unstandardized Coefficients } & Standardized & $\mathrm{t}$ & Sig. \\
\hline \multirow{3}{*}{1} & (Constant) & 3,180 & 847 & & 3,754 & ,000 \\
\hline & Pendidikan &,- 140 & 160 &,- 059 & -877 & ,383 \\
\hline & Pendapatan & ,759 & ,062 & ,824 & 12,173 & ,000 \\
\hline
\end{tabular}

a. Dependent Variable: Konsumsi

1) Pengaruh Tingkat Pendidikan 
Dari tabel 3 dapat dilihat bahwa variabel pendidikan $(X)$ menunjukkan nilai signifikan < a $(0.383>0.05)$ dengan nilai $a_{1}$ sebesar -0.140 , berarti variabel pendidikan tidak berpengaruh signifikan dan berhubungan negatif terhadap konsumsi pada taraf kepercayaan sebesar $95 \%$ dengan hasil tersebut maka hipotesis pertama tidak diterima.

2) Pengaruh Pendapatan

Dari tabel 3 dapat dilihat bahwa variabel tingkat pendapatan (X2) menunjukkan nilai signifikan < a $(0.000<0.05)$ dengan nilai $a_{2}$ sebesar 0.759 , berarti variabel tingkat pendapatan berpengaruh signifikan dan berhubungan positif terhadap konsumsi masyarakat migran pada taraf kepercayaan sebesar 95\%. Dengan hasil tersebut maka hipotesis kedua dapat diterima.

\section{Koefesien determinasi $\left(\mathbf{R}^{2}\right)$}

Uji koefesien determinasi ini dapat digunakan untuk mengukur seberapa jauh variabelvariabel bebas dalam menerangkan variabel terikatnya. Nilai koefesien determinasi untuk empat variabel bebas di tentukan dengan nilai adjusted $\mathrm{R}$ square. Adapun hasil koefesien determinasi dapat di lihat pada tabel 4 berikut:

Tabel 4 menunjukkan bahwa hasil dari perhitungan yang diperoleh dari koefesien determinasi yang telah disimbolkan dengan $R^{2}$ sebesar 0,640 . Dengan kata lain hal ini dapat menunjukkan bahwa besar persentase variasi pendapatan yang bisa dijelaskan oleh variasi variabel bebas yaitu tingkat pendidikan (X) sebesar 64\%, sedangkan sisanya 36\% dijelaskan oleh variabel-variabel yang tidak ada di dalam penelitian penelitian seperti tingkat suku bunga, harga barang, dan gaya hidup.

Tabel 4

Koefesien determinasi $\left(\mathrm{R}^{2}\right)$

Model Summary ${ }^{\mathrm{b}}$

\begin{tabular}{llll}
\hline Model & $\mathrm{R}$ & R Square \\
\hline 1 &, $800^{\mathrm{a}}$ &, 640 \\
\hline
\end{tabular}

a. Predictors: (Constant), Pendapatan, Pendidikan

b. Dependent Variable: Konsumsi

Sumber : Output SPSS 21 data diolah, tahun 2019

\section{Model 2 (Y2)}

\section{a. Uji simultan (uji F)}

Uji F merupakan uji secara simultan untuk mengetahui apakah variabel tingkat pendidikan dan pendapatan secara simultan mempunyai pengaruh yang signifikan terhadap konsumsi. Dari hasil analisis dapat dilihat pada tabel 5. 
Tabel 5

Hasil Uji Simultan (uji F)

ANOVA $^{a}$

\begin{tabular}{llrrrrr}
\hline Model & & Sum of Squares & df & Mean Square & F & Sig. \\
& & & & & & \\
\hline \multirow{3}{*}{1} & Regression & 197,994 & 3 & 65,998 & 28,517 &, $000^{\text {b }}$ \\
\cline { 2 - 7 } & Residual & 222,178 & 96 & 2,314 & & \\
\cline { 2 - 7 } & Total & 420,172 & 99 & & & \\
\hline
\end{tabular}

a. Dependent Variable: Kemiskinan

b. Predictors: (Constant), Konsumsi, Pendidikan, Pendapatan

Dari hasil regresi yang ditunjukkan pada tabel 5. Pengaruh variabel tingkat pendidikan (X1), pendapatan (X2), dan konsumsi (Y1) terhadap kemiskinan (Y2) maka diperoleh tingkat signifikansi $0,000<0,05$. Hal ini dapat menunjukkan bahwa ketiga variabel tersebut, yakni pendidikan (X1), pendapatan (X2), dan konsumsi (Y1) secara simultan berpengaruh signifikan terhadap variabel konsumsi.

\section{b. Uji Parsial (Uji t)}

Uji t merupakan uji secara parsial variabel independent (tingkat pendidikan dan pendapatan) terhadap variabel dependen (konsumsi).

1) Pengaruh Tingkat Pendidikan

Dari tabel 6 dapat dilihat bahwa variabel pendidikan (X1) menunjukkan nilai signifikan $>$ a $(0.444>0.05)$ dengan nilai $\beta_{1}$ sebesar -0.433 , berarti variabel pendidikan tidak berpengaruh signifikan dan berhubungan negatif terhadap konsumsi pada taraf kepercayaan sebesar 95\% dengan hasil tersebut maka hipotesis ketiga tidak diterima.

2) Pengaruh Pendapatan

Dari tabel 6 dapat dilihat bahwa variabel tingkat pendapatan (X2) menunjukkan nilai signifikan $<\mathrm{a}(0.000<0.05)$ dengan nilai $\beta_{2}$ sebesar -1.617 , berarti variabel tingkat pendapatan berpengaruh signifikan dan berhubungan positif terhadap konsumsi 
masyarakat migran pada taraf kepercayaan sebesar 95\%. Dengan hasil tersebut maka hipotesis keempat dapat diterima.

3) Pengaruh Konsumsi

Dari tabel 6 dapat dilihat bahwa variabel tingkat konsumsi (Y1) menunjukkan nilai signifikan > a $(0.638>0.05)$ dengan nilai $\beta_{3}$ sebesar -0.168 , berarti variabel tingkat konsumsi tidak berpengaruh signifikan dan berhubungan negatif terhadap konsumsi masyarakat migran pada taraf kepercayaan sebesar 95\%. Dengan hasil tersebut maka hipotesis kelima tidak dapat diterima.

Tabel 6

Hasil Uji Parsial (uji t)

Coefficients $^{\mathrm{a}}$

\begin{tabular}{|c|c|c|c|c|c|c|}
\hline \multirow[t]{2}{*}{ Model } & & \multicolumn{2}{|c|}{ Unstandardized Coefficients } & $\begin{array}{l}\text { Standardized } \\
\text { Coefficients }\end{array}$ & \multirow[t]{2}{*}{$t$} & \multirow[t]{2}{*}{ Sig. } \\
\hline & & $B$ & Std. Error & Beta & & \\
\hline \multirow{4}{*}{1} & (Constant) & $-9,840$ & 3,179 & & $-3,095$ & ,003 \\
\hline & Pendidikan &,- 433 & ,563 &,- 064 &,- 769 & 444 \\
\hline & Pendapatan & $-1,617$ & ,348 &,- 609 & $-4,650$ &, 000 \\
\hline & Konsumsi &,- 168 & ,356 &,- 058 &,- 472 & ,638 \\
\hline
\end{tabular}

a. Dependent Variable: Kemiskinan

Sumber: Output SPSS 21 data diolah, tahun 2019

\section{c. Koefesien determinasi $\left(\mathbf{R}^{2}\right)$}

Uji koefesien determinasi ini dapat digunakan untuk mengukur seberapa jauh variabelvariabel bebas dalam menerangkan variabel terikatnya. Nilai koefesien determinasi untuk empat variabel bebas di tentukan dengan nilai adjusted $\mathrm{R}$ square. Adapun hasil koefesien determinasi dapat di lihat pada tabel 7 berikut:

Tabel 7

Koefesien determinasi $\left(R^{2}\right)$

\begin{tabular}{lcccr}
\hline \multicolumn{4}{c}{ Model Summary $^{\mathbf{b}}$} & \\
\hline Model & $\mathrm{R}$ & & $\mathrm{R}$ Square & \\
\hline 1 & &, $686^{\mathrm{a}}$ & & 471
\end{tabular}

a. Predictors: (Constant), Konsumsi, Pendidikan, Pendapatan 
b. Dependent Variable: Kemiskinan

Sumber: Output SPSS 21 data diolah, tahun 2019

Tabel 7 menujukkan bahwa hasil dari perhitungan yang diperoleh dari koefesien determinasi yang disimbolkan dengan $\mathrm{R}^{2}$ sebesar 0,471. Dengan kata lain hal ini menunjukkan bahwa besar persentase variasi konsumsi yang bisa dijelaskan oleh variasi dari dua variabel bebas, yaitu tingkat pendidikan (X) dan pendapatan (Y1) sebesar $47 \%$ sedangkan sisanya 53\% dijelaskan oleh variabel-variabel yang tidak ada di dalam penelitian seperti tingkat suku bunga, harga barang, dan gaya hidup.

\section{KESIMPULAN / CONCLUSION}

Berdasarkan hasil penelitian yang telah dilakukan, maka dapat ditarik kesimpulan sebagai antara lain; Pendidikan tidak berpengaruh signifikan dan berpengaruh negatif terhadap konsumsi masyarakat migran di Kota Makassar. Pendapatan berpengaruh signifikan dan berpengaruh positif terhadap tingkat konsumsi masyarakat migran di Kota Makassar. Pendidikan tidak berpengaruh signifikan dan berpengaruh negatif terhadap tingkat kemiskinan masyarakat migran di Kota Makassar. Pendapatan berpengaruh signifikan dan berpengaruh negatif terhadap tingkat kemiskinan masyarakat migran di Kota Makassar. Konsumsi tidak berpengaruh signifikan dan berpengaruh negatif terhadap tingkat kemiskinan masyarakat migran di Kota Makassar. Pendidikan berpengaruh terhadap tingkat kemiskinan melalui konsumsi masyarakat migran di Kota Makassar. Pendapatan berpengaruh terhadap tingkat kemiskinan melalui konsumsi masyarakat migran di Kota Makassar.

Tingkat pendidikan semestinya menjadi perhatian khusus bagi pemerintah. Sebab kemiskinan kerap kali bermuara pada tingkat pendidikan yang rendah. Pendidikan, pendapatan, dan konsumsi merupakan suatu kesatuan yang berperan penting dalam peningkatan kemiskinan. Sudah seharusnya pemerintah mencari kebijakan untuk mengatasi kemiskinan dengan memperhatikan ketiga variabel tersebut. Untuk peneliti selanjutnya, masyarakat migran layak menjadi perhatian dalam isu pembangunan ekonomi. Apabila dilihat dari hasil penelitian ini, sumbangsih kemiskinan masyarakat migran di perkotaan cenderung berada pada tingkat menengah. Diharapkan peneliti selanjutnya untuk meneliti dampak migrasi di daerah asal. 


\section{DAFTAR PUSTAKA / REFERENCES}

Amalia, Alfi. 2017. Pengaruh Pendidikan, Pengangguran dan Ketimpangan Gender, Jurnal AtTawassuth, Vol. III, No.3.

Anggraini, Nita. 2012. Hubungan Kausalitas Dari Tingkat Pendidikan, Pendapatan, Dan Konsumsi Terhadap Jumlah Penduduk Miskin Di Provinsi Jawa Tengah. Skripsi. Fakultas Ekonomi Universitas Dipenogoro.

Arri Lestari; Kandowangko, Nicolas; dan Lasut, Jouke J. 2016. Peranan Pendidikan Dalam Meningkatkan Kehidupan Ekonomi Keluarga Di Desa Buhias Mantehage.https://ejournal.unsrat.ac.id/index.php/actadiurna/article/view/14277. Diakses 20 November 2018

Aulia, Syifa. 2012. Hipotesis Daur Hidup pada Konsumsi dan Tabungan Kaum Lansia, Skripsi Fakultas Ekonomi Universitas Negeri Jakarta.

Danil Mahyu. 2013. Pengaruh Pendapatan Terhadap Tingkat Konsumsi pada Pegawai Negeri Sipil Di Kantor Bupati kabupaten Bireuen, Jurnal ekonomika Universitas Almuslim Bireuen Vol. IV No.7.

Jhinghan. 2014. Ekonomi Pembangunan dan Perencanaan. Jakarta: PT RajaGrafindo Persada.

Ketut Suntajaya, I Gede. 2014. Faktor-Faktor Yang Mempengaruhi Terjadinya Urbanisasi Di Provinsi Bali, Jurnal Kependudukan dan Pengembangan Sumber Daya Manusia, Vol. 10 No.2.

Maha Neni. Pengertian, indikator dan penyebab kemiskinan", http://mahaneni.blogspot.com/2016/06/pengertian-indikator-dan-penyebab.html. Diakses 21 November 2018

Mahsunah Durrotul. 1999. Analisis Pengaruh Jumlah Penduduk, Pendidikan Dan Pengangguran Terhadap Kemiskinan Di Jawa Timur. Jurnal Ekonomi Unesa.

Martini Utari, Pengaruh Modal, Tingkat Pendidikan Dan Teknologi Terhadap Pendapatan Usaha Mikro Kecil Dan Menengah (Umkm) Di Kawasan Imam Bonjol Denpasar Barat, Jurnal Ekonomi Pembangunan UNUD.

Maulidah, Fadliyah. 2015. Pengaruh Tingkat Pendidikan, Pendapatan, dan Konsumsi Terhadap Jumlah Penduduk Miskin di Provinsi Jawa Timur, Jurnal Ekonomi Pendidikan dan Kewirausahaan, Vol. 3 No.1.

N. Gregory Mankiw. 2006. Makroekonomi Edisi Keenam Jakarta: PT. Gelora Aksara Pratama.

Ni Luh Karmini, Pande Putu Erwin Adiana. 2012. Pengaruh Pendapatan, Jumlah Anggota Keluarga, Dan Pendidikan Terhadap Pola Konsumsi Rumah Tangga Miskin Di Kecamatan Gianyar, Jurnal Ekonomi Universitas Udayana. Ni Luh Sili Antari, Pengaruh Pendapatan, Pendidikan, Dan Remitan Terhadap Pengeluaran Konsumsi Pekerja Migran Nonpermanen Di Kabupaten Badung.

Randi R. Giang. 2013. Pengaruh Pendapatan Terhadap Konsumsi Buruh Bangunan Di Kecamatan Pineleng, Jurnal EMBA. 
Rerungan, Kartika Astuti, Analisis Faktor-Faktor Yang Mempengaruhi Jumlah Penduduk Migran Masuk Risen (Kasus 4 Provinsi Di Sulawesi)

Sen, Amartya Kumar. 2000. Development as Freedom. New York: Anchor Books.

Setiawina Putri, Pengaruh Umur, Pendidikan, Pekerjaan Terhadap Pendapatan Rumah Tangga Miskin di Desa Bebandem, Jurnal Ekonomi Pembangunan UNUD

Sholihin Mangkugamo, "Kemiskinan dan Ukuran-ukurannya", diakses dari http://solihincityplan.blogspot.com/2009/04/kemiskinan-dan-ukuran-ukurannya.html

Sjafrizal.2012.Ekonomi Wilayah Dan Perkotaan. Jakarta: PT RajaGrafindo Persada.

Suryawati, Chriswardani. 2005. Memahami Kemiskinan Secara Multidimensional, Jurnal Manajemen Pelayanan Kesehatan, Vol. 08 No.03.

Todaro. 2000. Ekonomi Untuk Negara Berkembang: Jilid 2 Jakarta: PT Bumi Aksara.

Ustama, Dicky Djatnika. Peranan Pendidikan dalam Pengentasan Kemiskinan. Jurnal "DIALOGUE" JIAKP, Vol. 6, No. 1, Januari 2009:1-12

Yustika. 2009. Ekonomi Politik Kajian Teoritis dan Analisis Empiris Yogyakarta: Pustaka Pelajar. 